\title{
GENETIC DIVERSITY IN SODIUM AZIDE INDUCED WHEAT MUTANTS STUDIED BY SSR MARKERS
}

\author{
Ayşe ŞEN ${ }^{1 *}$, Fatma SARSU \\ ${ }^{1}$ Department of Biology, Faculty of Science, Istanbul University, 34134, Vezneciler, İstanbul, TURKEY \\ ${ }^{2}$ Plant Breeding and Genetics Section, Joint FAO/IAEA Division, Vienna International Centre, A-1400 Vienna, AUSTRIA \\ ORCID ID: orcid.org/0000-0002-1690-4536 \\ *Corresponding author: e-mail: senayse@istanbul.edu.tr
}

Cite this article as:

Şen A., Sarsu F. 2018. Genetic diversity in sodium azide induced wheat mutants studied by SSR markers. Trakya Univ J Nat Sci, 19(2): 129-135, DOI: $10.23902 /$ trkjnat.424305

Received: 16 May 2018, Accepted: 16 August 2018, Online First: 03 September 2018, Published: 15 October 2018

\begin{abstract}
Mutations induced artificially way are one of the tools used to increase genetic variation in populations where genetic variation has been shrinking especially due to various reasons one of which is domestication. In this study, Simple Sequence Repeats (SSRs) markers were used to screen genetic diversity in sodium azide $\left(\mathrm{NaN}_{3}\right)$ induced fourteen fourth-generation advanced wheat mutant lines. The mean values of polymorphism rate $(29.44 \%)$, polymorphic information content (PIC; 0.82), marker index (MI; 1.95) and resolving power (Rp; 1.31) were calculated according to SSR marker profiles. Two SSRs, Xwmc170 and Xcfd6, were detected as the most polymorphic markers, Xgwm626 proved the highest PIC and MI values, and Xcfd6 gave the highest Rp value. Unweighted Pair Group Method with Arithmetic Mean (UPGMA) dendrogram classified 15 plants into four groups. The Principle Component Analysis (PCA) showed 88.9\% of the total genetic variation. The results obtained in the present study might be useful for determining the efficiency of $\mathrm{NaN}_{3}$ for creating mutant wheat lines with enough genetic variability to implement wheat-breeding programs as germplasm resources.
\end{abstract}

Key words: Bread wheat, sodium azide mutagenesis, somatic embryogenesis, SSR markers, PCA, UPGMA.

Özet: Yapay yolla indüklenen mutasyonlar, genetik varyasyonun özellikle sslah gibi çeşitli nedenlerden dolayı küçüldüğü popülasyonlarda, çeşitliliği arttıran araçlardan biridir. Bu çalışmada, sodyum azid $\left(\mathrm{NaN}_{3}\right)$ kullanılarak indüklenen on dört dördüncü jenerasyon ileri mutant buğday hatlarında, genetik çeşitliliği taramak için Basit Dizi Tekrarları (SSR) belirteçleri kullanıldı. SSR belirteç profillerine göre ortalama polimorfizm oranı (\% 29,44), polimorfik bilgi içeriği (PIC; 0,82), belirteç indeksi (Mİ; 1,95) ve belirteç çözünürlük gücü (Rp; 1,31) hesaplandı. İki SSR belirteci, Xwmc170 ve Xcfd6, en yüksek polimorfizm oranına sahip belirteçler olarak tespit edildi. Xgwm626 en yüksek PIC ve Mİ değerlerini, Xcfd6 de en yüksek Rp değerini verdi. Ağırlıksız Çift-Grup Yöntemi ile Aritmetik Ortalama (UPGMA) dendrogramı 15 bitkiyi dört gruba ayırdı. Temel Bileşenler Analizi (PCA) toplam genetik varyasyonun \% 88,9'unu gösterdi. Bu çalışma, buğday islah programlarında genetik kaynak olarak kullanılmak üzere yeterli genetik çeşitliliğe sahip mutant buğday hatlarını oluşturmak için sodyum azitin etkinliğinin gösterilmesi hususunda yararlı olabilir.

\section{Introduction}

Wheat (Triticum aestivum L.) is one of the most important staple crops contributing substantially to food and nutritional security. Production and productivity of wheat are affected by several abiotic and biotic stress factors (Shewry 2009). Although some measures are taken to protect plant production and productivity against these stress factors, the ultimate solution is to develop novel lines, which are tolerant/resistant to these factors. In addition to the abiotic and biotic stress factors, loss of genetic diversity duo to monoculture farming or domestication is one of the distinct disadvantages, which put long-term yield production potential at risk. Grain yield is an important trait as it is considered as a measure of economic productivity in wheat. However, yield and its component traits are polygenic traits with low inheritance (Abdipour et al. 2016). On the other hand, induced genetic variability with mutation techniques brings about heritable changes in plants and offer new genetic varieties resistant to effects of climate change and tolerant to environmental stresses (www.iaea.org/topics/plantbreeding) or germplasm recourses to implement breeding programs. Chemical mutagens, like sodium azide $\left(\mathrm{NaN}_{3}\right)$ are frequently used in studies based on induced mutations (Al-Qurainy \& Khan 2009). Sodium-azide generally induces mutation bias on $\mathrm{AT} \rightarrow \mathrm{GC}$ base pair substitutions resulting in amino acid changes which in turn change the function of proteins and alter phenotypes (Olsen et al. 1993). Wannajindaporn et al. (2014) reported that 28 Dendrobium mutants were generated after exposure to $\mathrm{NaN}_{3}$ under in vitro conditions. 
DNA based molecular markers can be used to investigate the effects of mutagens. Among the molecular markers, microsatellites or SSRs are multiallelic, chromosome-specific, evenly distributed along chromosomes, and have been developed and widely used for studies of wheat genetic diversity (Mason 2015) and genetic mapping, such as association to salt tolerance in Triticum species (Genc et al. 2010, Xu et al. 2013, Sardouie-Nasab et al. 2013, Ghaedrahmati et al. 2014, Turki et al. 2015).

The aim of the present study was to identify genetic diversity in fourteen-fourth generation candidate wheat mutants induced with $\mathrm{NaN}_{3}$ application with SSR markers. Polymorphism rate (\%), polymorphic information content (PIC), marker index (MI), and resolving power $(\mathrm{Rp})$ were used to calculate according to SSR markers profile and the genetic distance among the candidate mutants was assessed by Principle Component Analysis (PCA) plots and Unweighted Pair Group Method with Arithmetic Mean (UPGMA) dendrograms.

\section{Materials and Methods}

\section{Materials}

Fourteen fourth generations advanced wheat mutant lines were used to screen genetic diversity via SSR markers. The cultivar used was the bread wheat cultivar
Adana 99 (Triticum aestivum L. cv.) and was obtained from the Eastern Mediterranean Agricultural Institute in Adana, Turkey. To obtain the mutant lines, two different concentrations ( 3 and $4 \mathrm{mM})$ of $\mathrm{NaN}_{3}(\mathrm{pH}$ $3.5)$ were applied under in vitro conditions to embryonic calli for 30 minutes in vitro conditions to induce genetic variations on the genome. Treated and non-treated embryonic calli were screened for salinity tolerance by putting $125 \mathrm{mM} \mathrm{NaCl}$ in indirect regeneration media. Then, the mutant lines were segregated up to fourth generation by combining in vitro and in vivo $\mathrm{NaCl}$ screening techniques. The treatment concentrations of $\mathrm{NaN}_{3}$ and $\mathrm{NaCl}$ were determined according to the results of preliminary experiments (Sen and Sarsu unpublished results).

\section{Genetic variability analysis}

\section{DNA isolation}

Frozen leaf bulks mixed from five plants from each mutant line $(500 \mathrm{mg})$ were ground in a mortar and pestle with liquid nitrogen. The isolation of the genomic DNA was performed with the CTAB method (Doyle \& Doyle 1990). The quality and quantity of the purified genomic DNA were estimated with spectrophotometry and gel electrophoresis. Each sample was diluted to $25 \mathrm{ng} \mu \mathrm{L}^{-1}$ in TE buffer and stored at $4^{\circ} \mathrm{C}$.

Table 1. SSR primers, localized chromosome, total number of alleles, polymorphic alleles, polymorphism ratios, PIC, MI and Rp.

\begin{tabular}{|c|c|c|c|c|c|c|c|c|}
\hline No & $\begin{array}{c}\text { Primer } \\
\text { Name }\end{array}$ & $\begin{array}{c}\text { Localized } \\
\text { Chromosomes }\end{array}$ & $\begin{array}{c}\text { Total Number of } \\
\text { alleles }\end{array}$ & $\begin{array}{c}\text { Polymorphic } \\
\text { alleles }\end{array}$ & $\begin{array}{l}\text { Polymorphism } \\
\text { rate }(\%)\end{array}$ & PIC & MI & Rp \\
\hline 1 & Xubc853b ${ }^{\mathrm{a}}$ & 1B & 3 & 1 & 33.33 & 0.50 & 0.50 & 0.93 \\
\hline 2 & $\mathrm{Xgwm} 10^{\mathrm{b}}$ & $2 \mathrm{~A}$ & 9 & 3 & 33.33 & 1.17 & 3.51 & 1.60 \\
\hline 3 & Xwmc261 ${ }^{\mathrm{b}}$ & $2 \mathrm{~A}$ & 6 & 3 & 50.00 & 1.03 & 3.09 & 1.47 \\
\hline 4 & $\underset{\mathrm{b}}{\mathrm{Xgwm} 294 \mathrm{~b}}$ & $2 \mathrm{~A}$ & 8 & 2 & 25.00 & 0.94 & 1.88 & 1.33 \\
\hline 5 & Xfca2121b & $2 \mathrm{~A}$ & 8 & 2 & 25.00 & 0.94 & 1.88 & 1.33 \\
\hline 6 & Xwmc296 & $2 \mathrm{~A}$ & 5 & 2 & 40.00 & 0.55 & 1.10 & 0.67 \\
\hline 7 & Xgwm515 & $2 \mathrm{~A}$ & 9 & 3 & 33.33 & 0.83 & 2.49 & 1.33 \\
\hline 8 & Xgwm95 & $2 \mathrm{~A}$ & 8 & 2 & 25.00 & 0.94 & 1.88 & 1.33 \\
\hline 9 & Xwmc $170^{\text {be }}$ & $2 \mathrm{~A}$ & 5 & 3 & 60.00 & 1.26 & 3.78 & 2.04 \\
\hline 10 & Xwmc $445 d^{a}$ & $2 \mathrm{~B}$ & 4 & 2 & 50.00 & 0.80 & 1.60 & 1.20 \\
\hline 11 & Xwmc1 $11^{\mathrm{b}}$ & $3 \mathrm{~A}$ & 5 & 1 & 20.00 & 0.50 & 0.50 & 0.93 \\
\hline 12 & Xgwm403c & $3 \mathrm{~A}$ & 8 & 0 & 0.00 & 0.00 & 0.00 & 0.00 \\
\hline 13 & Xgwm6 $^{\mathrm{a}}$ & $3 \mathrm{D}$ & 7 & 3 & 42.86 & 1.26 & 3.78 & 1.73 \\
\hline 14 & Xgwm538 & $4 B$ & 9 & 2 & 22.22 & 0.82 & 1.64 & 1.33 \\
\hline 15 & Xwmc413 ${ }^{a}$ & $4 B$ & 7 & 2 & 28.57 & 0.55 & 1.10 & 0.67 \\
\hline 16 & Xgwm194 $4^{\mathrm{b}}$ & $4 B$ & 6 & 2 & 33.33 & 0.69 & 1.38 & 0.80 \\
\hline 17 & Xgwm624 & $4 \mathrm{D}$ & 8 & 0 & 0.00 & 0.00 & 0.00 & 0.00 \\
\hline 18 & Xgwm540d & $4 \mathrm{D}$ & 9 & 3 & 33.33 & 0.76 & 2.28 & 1.07 \\
\hline 19 & Xcfd080 & $5 B$ & 8 & 2 & 25.00 & 0.96 & 1.92 & 1.60 \\
\hline 20 & Xgwm626 $6^{\mathrm{d}}$ & $5 \mathrm{D}$ & 6 & 3 & 50.00 & 1.40 & 4.20 & 1.86 \\
\hline 21 & Xgwm88 & $5 \mathrm{D}$ & 7 & 2 & 28.57 & 0.96 & 1.92 & 1.60 \\
\hline 22 & Xwmc416 & $6 \mathrm{~A}$ & 4 & 1 & 25.00 & 0.50 & 0.50 & 1.07 \\
\hline 23 & Xwmc83a & $6 \mathrm{~B}$ & 10 & 2 & 20.00 & 0.98 & 1.96 & 1.73 \\
\hline 24 & $\mathrm{Xgwm} 4^{\mathrm{c}}$ & $6 \mathrm{~B}$ & 8 & 3 & 37.50 & 0.92 & 2.76 & 1.73 \\
\hline 25 & Xcfd $6^{c}$ & $6 \mathrm{D}$ & 5 & 3 & 60.00 & 1.32 & 3.96 & 3.86 \\
\hline 26 & Xubc $853 b^{a}$ & $7 \mathrm{~A}$ & 9 & 2 & 22.22 & 0.80 & 1.60 & 1.20 \\
\hline 27 & Xgwm10 $0^{\mathrm{b}}$ & $7 \mathrm{~A}$ & 12 & 3 & 25.00 & 0.94 & 2.82 & 1.33 \\
\hline \multirow[t]{3}{*}{28} & Xwmc $261^{\mathrm{b}}$ & $7 \mathrm{~A}$ & 4 & 1 & 25.00 & 0.50 & 0.50 & 1.07 \\
\hline & Total & & 197 & 58 & - & - & - & - \\
\hline & Mean & & 7.04 & 2.07 & 29.44 & 0.82 & 1.95 & 1.31 \\
\hline
\end{tabular}

$\overline{\mathrm{a}}\left(\mathrm{Xu}\right.$ et al. 2013), ${ }^{\mathrm{b}}$ (Sardouie-Nasab et al. 2013), ${ }^{\mathrm{c}}$ (Turki et al. 2015), ${ }^{\mathrm{d}}\left(\right.$ Ghaedrahmati et al. 2014), ${ }^{\mathrm{e}}($ Genc et al. 2010). 


\section{PCR Amplification}

Genomic diversity was analyzed through 28 SSR markers previously determined to be related with salt tolerance (Table 1). In SSR analysis, the reaction mixture, $25 \mu \mathrm{L}$ in total, consisted of $400 \mathrm{nmol}$ of forward and reverse SSR primers, $0.2 \mathrm{mM}$ of each nucleotide, $2.5 \mathrm{mM}$ $\mathrm{MgCl}_{2}, 10 x$ Polymerase Chain Reaction (PCR) buffer, 1 unit of Taq-DNA polymerase, and $75 \mathrm{ng}$ of genomic DNA. The PCR conditions, separation of the amplified fragments on $2.5 \%$ agarose gel electrophoresis and gel staining were carried out following Shahzad et al. (2012).

\section{Data analyses}

Comparison of mutants was carried out based on the presence or absence of fragments produced by SSR primer amplifications. The Multivariate Statistical Package v3.1 (Kovach 1999) was used to estimate the genetic diversity with Nei and Li's similarity coefficients to construct a UPGMA dendrogram with a neighborjoining algorithm (Nei \& Li 1979) and control and mutant scores were plotted with a PCA from a matrix according to Nei and Li's (1979) genetic similarity. Dissimilarity (D) matrices were based on the equation $D=1-S$, where $S$ is genetic similarity. PIC, MI, and Rp were calculated according to Anderson et al. (1993), Powell et al. (1996), and Prevost \& Wilkinson (1999), respectively.

\section{Results}

\section{SSR based diversity in wheat mutants}

The PCR analysis showed that a total of 197 alleles were amplified and 58 of these were polymorphic $(29.44 \%)$. The number of alleles per locus ranged from 3 (Xubc853b) to 12 (Xgwm10) with an average of 7.04 alleles per locus (Table 1).

The mean values of PIC, MI, and Rp were detected as a $0.82,1.95$, and 1.31 , respectively. The highest PIC and MI values were obtained with the primer Xgwm626 and the highest $\mathrm{Rp}$ value was obtained with the primer Xcfd6. Most of the PIC values were recorded above 0.5 , indicating that they were informative and useful (Table 1).

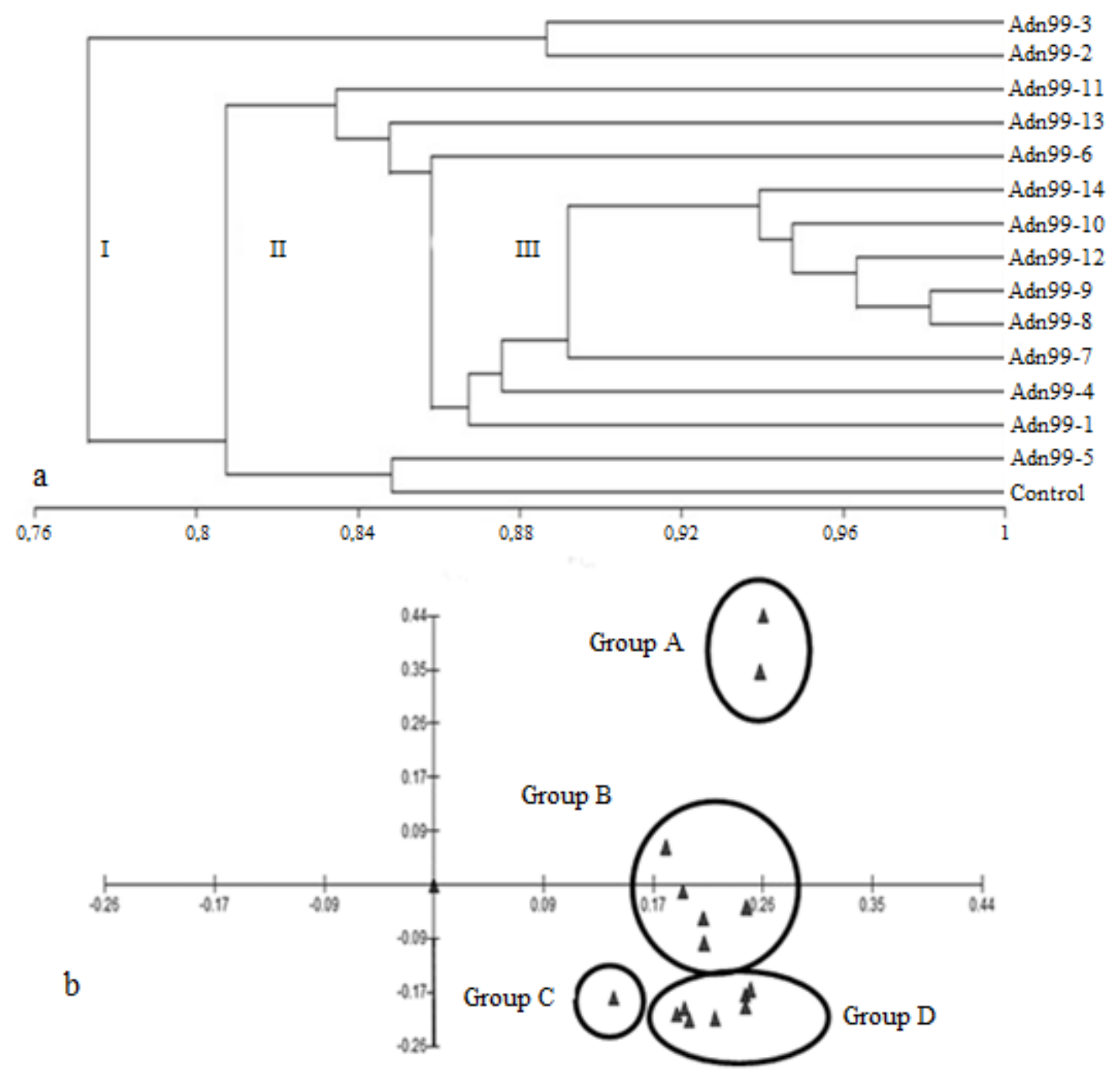

Fig. 1. UPGMA dendrogram of SSR data using Nei and Li's coefficient (a) and PCA plot of SSR data (b) showing relationships between the control and the mutant lines. 
Table 2. The genetic distances between the control and the mutant lines based on Nei and Li's coefficient using banding patterns of SSR primers.

\begin{tabular}{|c|c|c|c|c|c|c|c|c|c|c|c|c|c|c|c|}
\hline $\begin{array}{l}\text { Experimental } \\
\text { Groups }\end{array}$ & Control & $\begin{array}{c}\text { Adn99- } \\
1\end{array}$ & $\begin{array}{c}\text { Adn99- } \\
2\end{array}$ & $\begin{array}{c}\text { Adn99- } \\
3\end{array}$ & $\begin{array}{c}\text { Adn99- } \\
4\end{array}$ & $\begin{array}{c}\text { Adn99- } \\
5\end{array}$ & $\begin{array}{c}\text { Adn99- } \\
6\end{array}$ & $\begin{array}{c}\text { Adn99- } \\
7\end{array}$ & $\begin{array}{c}\text { Adn99- } \\
8\end{array}$ & $\begin{array}{c}\text { Adn99- } \\
9\end{array}$ & $\begin{array}{c}\text { Adn99- } \\
10\end{array}$ & $\begin{array}{c}\text { Adn99- } \\
11\end{array}$ & $\begin{array}{c}\text { Adn99- } \\
12\end{array}$ & $\begin{array}{c}\text { Adn99- } \\
13\end{array}$ & $\begin{array}{c}\text { Adn99- } \\
14\end{array}$ \\
\hline Control & 0.000 & & & & & & & & & & & & & & \\
\hline Adn99-1 & 0.174 & 0.000 & & & & & & & & & & & & & \\
\hline Adn99-2 & 0.255 & 0.236 & 0.000 & & & & & & & & & & & & \\
\hline Adn99-3 & 0.223 & 0.189 & 0.113 & 0.000 & & & & & & & & & & & \\
\hline Adn99-4 & 0.149 & 0.179 & 0.274 & 0.228 & 0.000 & & & & & & & & & & \\
\hline Adn99-5 & 0.152 & 0.183 & 0.264 & 0.200 & 0.142 & 0.000 & & & & & & & & & \\
\hline Adn99-6 & 0.168 & 0.150 & 0.248 & 0.216 & 0.142 & 0.161 & 0.000 & & & & & & & & \\
\hline Adn99-7 & 0.197 & 0.148 & 0.274 & 0.243 & 0.139 & 0.174 & 0.125 & 0.000 & & & & & & & \\
\hline Adn99-8 & 0.198 & 0.116 & 0.213 & 0.182 & 0.124 & 0.175 & 0.143 & 0.107 & 0.000 & & & & & & \\
\hline Adn99-9 & 0.181 & 0.098 & 0.227 & 0.164 & 0.106 & 0.158 & 0.125 & 0.089 & 0.019 & 0.000 & & & & & \\
\hline Adn99-10 & 0.216 & 0.117 & 0.231 & 0.167 & 0.142 & 0.193 & 0.161 & 0.125 & 0.056 & 0.037 & 0.000 & & & & \\
\hline Adn99-11 & 0.284 & 0.189 & 0.223 & 0.173 & 0.212 & 0.263 & 0.232 & 0.196 & 0.131 & 0.112 & 0.096 & 0.000 & & & \\
\hline Adn99-12 & 0.203 & 0.123 & 0.250 & 0.187 & 0.114 & 0.149 & 0.133 & 0.097 & 0.046 & 0.028 & 0.064 & 0.138 & 0.000 & & \\
\hline Adn99-13 & 0.231 & 0.169 & 0.308 & 0.248 & 0.176 & 0.240 & 0.210 & 0.192 & 0.130 & 0.113 & 0.132 & 0.202 & 0.137 & 0.000 & \\
\hline Adn99-14 & 0.210 & 0.147 & 0.257 & 0.211 & 0.122 & 0.188 & 0.157 & 0.122 & 0.055 & 0.054 & 0.073 & 0.145 & 0.062 & 0.112 & 0.000 \\
\hline
\end{tabular}


Table 3. Eigenvectors, eigenvalues, and percentage of variance for six principal components based on SSR data from the control and the mutant lines.

\begin{tabular}{lcccccc}
\hline \hline Genotype & PC 1 & PC 2 & PC 3 & PC 4 & PC 5 & PC 6 \\
\hline \hline Control & 0.185 & 0.062 & -0.498 & -0.127 & -0.313 & 0.133 \\
Adn99-1 & 0.215 & -0.055 & 0.013 & -0.563 & 0.059 & -0.065 \\
Adn99-2 & 0.263 & 0.437 & 0.074 & 0.092 & 0.123 & 0.377 \\
Adn99-3 & 0.261 & 0.346 & 0.100 & 0.071 & -0.085 & -0.394 \\
Adn99-4 & 0.200 & -0.201 & -0.229 & 0.366 & -0.025 & -0.005 \\
Adn99-5 & 0.198 & -0.011 & -0.295 & 0.093 & 0.243 & -0.513 \\
Adn99-6 & 0.216 & -0.094 & -0.176 & -0.052 & 0.420 & 0.106 \\
Adn99-7 & 0.194 & -0.211 & -0.025 & -0.016 & 0.435 & 0.174 \\
Adn99-8 & 0.248 & -0.178 & 0.143 & 0.019 & 0.007 & 0.139 \\
Adn99-9 & 0.249 & -0.199 & 0.121 & -0.005 & -0.024 & -0.011 \\
Adn99-10 & 0253 & -0.170 & 0.201 & -0.019 & -0.114 & -0.041 \\
Adn99-11 & 0.249 & -0.037 & 0.323 & 0.085 & -0.170 & -0.033 \\
Adn99-12 & 0.225 & -0.216 & 0.119 & 0.060 & 0.111 & -0.091 \\
Adn99-13 & 0.143 & -0.184 & 0.174 & -0.033 & -0.512 & 0.106 \\
Adn99-14 & 0.204 & -0.220 & 0.157 & 0.120 & -0.091 & 0.124 \\
\hline Eigen-values & 1.883 & 0.349 & 0.286 & 0.157 & 0.109 & 0.096 \\
Percentage & 58.137 & 10.765 & 8.882 & 4.851 & 3.386 & 2.956 \\
Cumulative \% & 58.137 & 68.902 & 77.721 & 82.573 & 85.940 & 88.896 \\
\hline \hline
\end{tabular}

\section{Phylogenetic relationship as revealed by SSR markers}

The data from all 15 plants and 197 alleles produced by SSR primers were compiled and analyzed using Nei and Li's coefficient. The analysis showed that genetic differences between pairs of mutants ranged from 0.019 (Adn99-8 and Adn99-59) to 0.308 (Adn99-13 and Adn992) with an average difference value of 0.203 between control and mutant lines (Table 2).

The results obtained with the cluster analysis are given in Fig. 1a. The UPGMA dendrogram classified the mutants into four major clusters, the first with two mutant lines (Adn99-2 and Adn99-3), the second with three mutant lines (Adn99-11, Adn99-13 and Adn99-5) and the control, the third with three mutant lines (Adn99-6, Adn99-1, and Adn99-4) and the fourth with six mutant lines (Adn99-7, Adn99-8, Adn99-9, Adn99-10, Adn99-12 and Adn99-14).

In order to complement the cluster analysis, a PCA plot was constructed with SSR data. Eigenvectors, eigenvalues, and proportion of accounted variance for each variable are shown in Table 3. The Principle Component (PC) 1 had an eigenvalue of 1.883 , the PCs 2 , $3,4,5$, and 6 had eigenvalues of $0.349,0.286,0.157$, 0.109 , and 0.096 , respectively. The first six variables accounted for $88.896 \%$ of the total variance (Table 3 ). The control and the mutant lines were grouped into four groups (termed as group A-D) according to the six principal components (Fig. 1b). Group A had two mutant lines (Adn99-2 and Adn99-3), group B had five mutant lines (Control, Adn99-1, Adn99-5, Adn99-6, and Adn9911), Group C had one mutant line (Adn99-13), and Group D had seven mutant lines (Adn99-4, Adn99-7, Adn99-8, Adn99-9, Adn99-10, Adn99-12 and Adn99-14). Both the cluster analysis and the principle component analysis classified the control and the mutant lines in four clusters/groups but the groupings were not identical.

\section{Discussion}

In this study, fourteen fourth-generation advanced mutant lines were used to screen genetic diversity induced by $\mathrm{NaN}_{3}$ application via SSR markers. Chemical mutagens tend to cause random point mutations (transitions and transversions) and small insertions/deletions (InDels) in whole target genome. As a result, loss- or gain-of-function mutations can occur leading to formation of different phenotypes. A number of techniques have been developed to detect natural or mutagen induced Single Nucleotid Polymorphisms (SNPs) and InDels in whole genome. Among these techniques, PCR based molecular marker techniques have been widely used in genotyping in mutants. For instance, Wannajindaporn et al. (2014) reported a $22.5 \%$ polymorphism ratio in $\mathrm{NaN}_{3}$ induced Dendrobium "Earsakum" mutants using inter simple sequence repeats (ISSR) markers. Polymorphism ratio in our present study was measured as $29.44 \%$.

Marker attributes such as PIC, MI, and Rp indicate the informativeness of primer combinations and are widely used in genetic diversity studies in natural populations 
instead of mutant lines. The average PIC and MI values for Turkish wheat varieties, as revealed by SSR markers, were detected as 0.52 and 1.84, respectively (Akfirat \& Uncuoglu 2013). These average values are lower than values determined in our study. Turki et al. (2015) reported that wmc633 detected the highest number of alleles and PIC value among 119 durum wheat varieties. The average of PIC, MI and Rp values for Iranian wheat cultivars and breeding lines were calculated as $0.22,1.34$ and 12 , respectively using 10 ISSR markers (Najaphy et al. 2011).

Wu et al. et al. (2011) reported in their study based on ISSR molecular maker technique that $\mathrm{NaN}_{3}$ applied Chlorophytum showed genetic differences ranging from 0.141 to 0.402 with an average of 0.2715 . In the Turkish wheat population, the rate of genetic differences was reported between 0.367 and 0.521 (Akfirat \& Uncuoglu 2013) and these values are higher genetic difference values determined in the present study.

PCA is a multivariate analysis method that allows the simultaneous evaluation of numerous variables, reduces variations to a manageable level, and visualizes the results

\section{References}

1. Abdipour, M., Ebrahim, M., Izadi-Darbandi, A., Mastrangelo, A.M., Najafian, G., Arshad, Y. \& Mirniyam, G. 2016. Association between grain size and shape and quality traits, and path analysis of thousand-grain weight in Iranian bread wheat landraces from different geographic regions. Notulae Botanicae Horti Agrobotanici ClujNapoca, 44: 228-236.

2. Akfirat, S.F. \& Uncuoglu, A.A. 2013. Genetic diversity of winter wheat (Triticum aestivum L.) revealed by SSR Markers. Biochemical Genetics, 51: 223-229.

3. Al-Qurainy, F. \& Khan, S. 2009. Mutagenic effects of sodium azide and its application in crop improvement. World Applied Sciences Journal, 6(12): 1589-1601.

4. Anderson, J.A., Churchill, G.A., Autrique, J.E., Tanksley, S.D. \& Sorrells, M.E. 1993. Optimizing parental selection for genetic linkage maps. Genome, 36(1): 181-186.

5. Doyle, J.J. \& Doyle, J.L. 1990. Isolation of plant DNA from fresh tissue. Focus, 12: 13-15.

6. Genc, Y., Oldach, K., Verbyla, A.P., Lott, G., Hassan, M., Tester, M., Wallwork, H. \& McDonald, G.K. 2010. Sodium exclusion QTL associated with improved seedling growth in bread wheat under saline stress. Theoretical Applied Genetics, 121: 877-894.

7. Ghaedrahmati, M., Mardi, M., Naghavi, M.R., Haravan, E.M., Nakhoda, B., Azadi, A. \& Kazemi, M. 2014. Mapping QTLs associated with salt tolerance related traits in seedling stage of wheat (Triticum aestivum L.). Journal of Agricultural Science and Technology, 16: 1413-1428.

8. International Atomic Energy Agency, www.iaea.org/topics/plant-breeding. (Data Accessed: May 2018).

9. Kovach, W.L. 1999. MVSP-A Multivariate Statistical Package for Windows, v. 3.1. Kovach Computing Services, Pentraeth, $133 \mathrm{pp}$. in 2- or 3-dimensional plots for interpretation and analysis. In other words, PCA makes it possible to extract rich information from genetic data, assign individuals to the groups, make visual assessments of betweenpopulation differences, and assess the contribution of individual alleles to population structuring (LasalitaZapico \& Aguilar 2014). In our study, the results of both UPGMA and PCA classified the control and mutant lines in four major groups but the groupings were not identical. Akfirat \& Uncuoglu (2013) reported that UPGMA based on genetic distance estimates produced two groupings according to SSR data results.

In conclusion, overall results demonstrated that chemical mutagenesis has an effect on generating mutant lines for implementing genetic resource in wheat breeding programs.

\section{Acknowledgement}

This study was supported by The Research Fund of Istanbul University by Project Numbers: BEK-201724939, 24750, 45260 and 49463 to AS.

10. Lasalita- Zapico, F. \& Aguilar, C.H. 2014. Elucidating plant genetic diversity and evolution through bioinformatics: a review of selected studies. 2014. International Conference on Intelligent Agriculture, IPCBEE 63(2014) IACSIT Press, Singapore, DOI: 10.7763/IPCBEE. 2014. V63.6.

11. Mason, A.S. 2015. SSR Genotyping, Plant Genotyping: Methods and Protocols, In: Batley, J. editor. Methods in Molecular Biology, vol. 1245, Springer Science Business Media, New York, 77-89 pp.

12. Najaphy, A., Parchin, R.A. \& Farshadfar, E. 2011. Evaluation of genetic diversity in wheat cultivars and breeding lines using Inter Simple Sequence Repeat markers. Biotechnology \& Biotechnological Equipment, 25: 2634-2638.

13. Nei, M. \& Li, W. 1979. Mathematical model for studying genetic variation in terms of restriction endonucleases. Proceedings of the National Academy of Sciences of the United States of America, 76: 5269-5273.

14. Olsen, O., Wang, X. \& Von Wetttesin, D. 1993. Sodium azide mutagenesis: Preferential generation of AT $\rightarrow$ GC transitions in the barley Antl8 gene. Proceedings of the National Academy of Sciences of the United States of America, 90: 8043-8047.

15. Powell, W., Morgante, M., Andre, C., Hanafey, M., Vogel, J., Tingey, S. \& Rafalski, A. 1996. The comparison of RFLP, RAPD, AFLP SSR (microsatellite) marker for germplasm analysis. Molecular Breeding, 2: 225-238.

16. Prevost, A. \& Wilkinson, M.J. 1999. A new system of comparing PCR primers applied to ISSR finger printing of potato cultivars. Theoretical Applied Genetics, 98: 661668.

17. Sardouie-Nasab, S., Mohammadi-Nejad, G. \& Zebarjadi, A. 2013. Haplotype analysis of QTLs attributed to salinity 
tolerance in wheat (Triticum aestivum). Molecular Biology Reports, 40: 4661-4671.

18. Shahzad, A., Ahmad, M., Iqbal, M., Ahmed, I. \& Ali, G.M. 2012. Evaluation of wheat landrace genotypes for salinity tolerance at vegetative stage by using morphological and molecular markers. Genetics and Molecular Research, 11: $679-692$.

19. Shewry, P.R. 2009. Wheat. Journal of Experimental Botany, 60: 1537-1553.

20. Turki, N., Shehzad, T., Harrabi, M. \& Okuno, K. 2015. Detection of QTLs associated with salinity tolerance in durum wheat based on association analysis. Euphytica, 201: 29-41.
21. Wannajindaporn, A., Poolsawat, O., Chaowiset, W. \& Tantasawat, P.A. 2014. Evaluation of genetic variability in in vitro sodium azide-induced Dendrobium 'Earsakul' mutants. Genetics and Molecular Research, 13: 53335342 .

22. Wu, L., Li, M., Yang, X., Yang, T. \& Wang, J. 2011. ISSR Analysis of Chlorophytum treated by three kinds of chemical mutagen. Journal of Northeast Agricultural University, 18: 21-25.

23. Xu, Y., Li, S., Li, L., Zhang, X., Xu, H. \& An, D. 2013. Mapping QTLs for salt tolerance with additive, epistatic and QTL $\times$ treatment interaction effects at seedling stage in wheat. Plant Breeding, 132: 276-283. 
